\title{
The School Committee's Roles in Improving Education Quality at Primary School Level
}

\author{
Ahmad Sopingi ${ }^{1 *}$, Yasir Arafat ${ }^{2}$, Dessy Wardiah $^{2}$ \\ ${ }^{1}$ SD Negeri 18 Muara Telang \\ ${ }^{2}$ Universitas PGRI Palembang \\ *Corresponding author. E-mail: ahmadsopingi29@gmail.com
}

\begin{abstract}
This paper aims to describe the school committee's role in improving the quality of primary school education in cluster 01 of Muara Telang sub-district, Banyuasin district. The research method used in this paper is a qualitative research method with descriptive analysis. The data collection techniques are conducted by interviews, observations, and documentation. The informants in this study were the principals and school committee. Triangulation techniques are applied to validate the data. The results of this study found that the school committee has many roles. These include (1) an advisory agency, to giving considerations in determining school policies and programs, school work budget plans, school performance, and facilities, (2) a supporting agency in the implementation and improving the quality of education in financial support, (3) a supervisor of educational services in schools, (4) a mediator or liaison between parents' aspirations to the school and participate in socializing school policy to the relevant parties and authorities at the regional level.
\end{abstract}

Keywords: School Committee Role, Quality of Education.

\section{INTRODUCTION}

The development of education determines the development of science. Education has a very strategic role in determining the direction of progress or retreat of education quality. This can be felt when an educational institution provides the right way and can be seen from the quality. Unlike educational institutions that carry out education just by, the results are ordinary. One of the Indonesian educational problems is the low quality of education at every level and education unit, mostly primary and secondary education. Various efforts have been made to improve the quality of national education through various training and improving teacher competencies and teaching duties in the education process by instilling students' attitudes and values. Therefore, the teacher also serves as a coach, supervisor, and learning manager. However, various indicators of the quality of education have not shown any significant improvement. Some schools, especially in cities, show encouraging improvement in education quality, but others are still concerned.

A nation's future can be known through the extent of society's commitment, nation, or state in organizing national education. Education is one of the pillars of the nation's life. Therefore, education is needed so that the desired behavior can become a habit. Education becomes the primary or decisive factor for the future of the nation. National education is stated in [7] article 3, which states that it aims to develop the potential of learners to become human beings who believe and believe in God almighty, noble, healthy, knowledgeable, capable, creative, independent and become democratic and responsible citizens.

Concerning education, [6] stated that, as quoted by Mulyasa, national education today is faced with four significant crises: quality, relevance, or external efficiency, elitism, and management. Furthermore, it is stated that there are at least six main problems related to the national education system: 1) decreased morale and morale of learners, 2) equitable learning opportunities, 3) low internal efficiency of the education system, 4) institutional status, 5) education management that is not in line with national development, and 6) resources that are relatively minimal and unprofessional.

These six problems are the impact of Indonesia's chaotic and uncertain education system. The decline in learners' morality and morale is caused by a curriculum that does not follow the times. That is, an educational process must be oriented to the needs of learners. All the potentials that students have, namely intellectual, mental, and physical potentials, must be built in an integrated manner in harmony, harmony, and balance 
drawn in the human figure as a whole. Furthermore, teach learners always to respect both parents, carry out deeds Amar ma'ruf and nahi Munkar, and teach learners to carry out human relationships by doing good deeds, attitudes, and behaviors in the association as simplicity in communicating with others.

Educators must inclusively develop religious and human values in interacting with individuals, families, and communities because every individual has the full right to live freely and get humane treatment. Efforts to improve the quality of education in Indonesia are currently sustainable. New concepts and insights will continue to be processed as knowledge and technology evolve. The new concepts and insights are expected to improve the quality of human resources in order to be able to compete globally. Thus the issue of improving the quality of education is fundamental to be reviewed and fought for. In realizing the struggle in improving the quality of education, there needs to be an improvement in human resources, educational institutions such as elementary, junior high, high school, vocational school, and universities. All of them need to be supported by proper educator resources. Education resources include experts or teachers, management, curriculum, facilities, infrastructure, and funds held and utilized by the government, communities, families, and learners both individually and in the form of cooperation.

The granting of broad educational autonomy to schools is the government's concern for the symptoms that arise in the community and efforts to improve education quality in general. The granting of autonomy demands a more conducive management approach in schools to accommodate all desires while empowering various society components effectively to support progress and systems in schools. In this framework, School-Based Management (SBM) appears as an alternative to the new paradigm of education management offered. School-Based Management is a concept that offers autonomy to schools to determine school policies in order to improve the quality, efficiency, and equity of education in order to accommodate the needs of the community and the government. Implementing School-Based Management requires the community's participation and support, both in the management and management of education is urgently needed.

Furthermore, to accommodate the community's participation in the world of education, a school committee was formed. The central concept where education is an essential element in a country to develop human resources, therefore education must be more considered because it can be used as a tool or goal in the struggle to achieve the nation's ideals. Therefore, every educational program must be optimally pursued to develop personality, instill knowledge, and improve learners' quality.

Such needs, especially achieving the ideals of the nation, the government always strives to improve the quality of education in the hope that it can produce citizens who are taqwa, smart, skilled as well as healthy physically and spiritually, must be enforced in the Law of the Republic of Indonesia Number 20 the Year 2003 on the National Education System Article 3

"... National education is to form dignified national character and civility in order to educate the life of the nation, aiming to develop the potential of learners to become human beings who believe and believe in God almighty, noble character, knowledgeable, capable, creative, independent, and become democratic citizens and responsibilities."

Achieving the above exposure to the Law of the Republic of Indonesia Number 20 the year 2003 concerning the national education system, Article 3 states the need for quality education at every level and educational unit, especially primary and secondary education. Various efforts have been made to improve the quality of national education management, among others, through various training and improvement of teacher competencies, procurement of books and learning tools, improvement of educational facilities and infrastructure, and improving school management quality. However, various quality indicators of education management have not shown significant improvement, such as lack of learning facilities. Based on this problem, to improve the quality of education and the ways mentioned above, there is also a need to improve quality-oriented control implementation. This activity can be carried out by the principal or by the education supervisor.

According to [1] [2], several factors cause education quality does not improve evenly. One factor is the participation of school residents, especially teachers, and the community's participation, especially parents of students in education so far, is very minimal. Community participation has generally been limited to funding support, while other support such as thought, morals, and goods/services are less noticed. The existence of this school committee has referred to Law No. 25 of 2000 on The National Development Program (2000-2004), in order to empower and increase the participation of the community needs to be established education councils at the district/city level, and school committees at the education unit level. This mandate is in line with the conception of decentralization of education at the district/city level and the school level. The mandate of the people in the Law has been followed up with the decree of the Minister of National Education No. 004/U/2002 dated April 2 concerning the board of education and school committees.

In Appendix II, the Decree of the Minister of National Education No. 044/U/2002 dated April 2, 2002, concerning the Reference for the Establishment of School Committees, it is stated that school committees' existence plays the following role: 1 . It is considering the determination and implementation of education policy in the education unit; 2. Supporters, both in the form of financial, ideas and energy, in the education unit; 3. Controller, in the framework of transparency and accountability of the implementation and output of 
education in education unit; 4. Mediator between the government and the community in the education unit.

Based on the decision of the Ministry of Education, the school committee is an independent organization that accommodates the participation of the community in order to improve the quality, equity, and efficiency of education management in the education unit both in preschool education, school education pathways, and outside-school education pathways. Organizations adapted to each district education unit's conditions and needs, such as school committees, madrasah assemblies, school assemblies, and kindergarten committees. The purpose of the school committee is 1). Accommodate and convey the community's aspirations and initiatives in creating operational policies and educational programs in the education unit; 2). Increase the responsibility and role of the community in the implementation of education; and $3)$. Create an atmosphere and conditions transparent, accountable, and democratic in implementing and quality service in the unity of education.

Education boards and school committees' existence are considered strategic to improve education quality, especially in Indonesia. Some community groups and education experts, and observers who are invited to provide input in efforts to improve the quality of education are generally very enthusiastic and fully support the idea of establishing education boards and school committees. To empower and increase community participation, schools must foster cooperation with parents and the community, creating a conducive and pleasant atmosphere for students and school residents. That is why the paradigm of SBM contains meaning as participatory management that involves the community's participation so that all policies and decisions taken are policies and joint decisions to achieve success. This participation needs to be managed and appropriately coordinated to be more meaningful for schools, especially in improving education quality and effectiveness through a forum, namely the education board at the district/city level and school committees in each education unit.

This aims to improve all social elements to participate in their children's education with better quality. Therefore, this is part of government policies' response in several Laws and Decrees of the Minister of National Education related to community participation to realize quality education. Based on this fact, improvement efforts are needed to significantly increase the community's participation (parents) in various educational programs. The participation and support of the community both in the management and implementation of education are urgently needed. The school committee was formed to accommodate the community's participation in the world of education to improve the quality of education (Suparlan, 2008: 205). The school will fully engage the school committee if it has anything to do with school funding that requires assistance from the community. In this case, the school committee is at the forefront of explaining to the community. However, in school management, financial management, and school policy determination, the school committee is less involved [3].

Based on the Minister of Education and Culture Number 75 of 2016, the school committee improves education management quality and carries out its functions in a mutually democratic, independent, professional, and accountable manner. However, in reality, so far, community participation in education is more at the level of concept, discourse, and still far from what is expected [5]. From the various experiences and facts that exist, the school's implementation of the school committee's role is not as easy as the theory. This happens because there is still a public understanding of the old pattern where the whole program is always from top to bottom regardless of the surrounding community's needs. Also, there is often a misconception that education is only the duty of teachers and the government, whereas the community has never felt that it has to advance education. It is also what underlies the researchers choosing to conduct this study. The researchers know that in the scope of cluster 01 Muara Telang sub-district that, the committee's role very minimal than ideal. Meanwhile, researchers see great potential for committees in each school as partners to improve and even ensure education quality.

\section{METHODS}

The method used in this research uses a qualitative approach. [4] defines qualitative methodology as a research procedure that produces descriptive data in written or spoken words from people and observable behavior. This approach is directed at holistic (whole) backgrounds and individuals, so it should not isolate individuals or organizations into variables and hypotheses, but it is necessary to look at them out of a need. Based on the above exposure, then as a characteristic of this qualitative approach, researchers cannot represent others because the researchers themselves are the key instruments in extracting information from the research subjects. The key informant in this study is the principal. The study's subject in question is the main actors carrying out their duties and responsibilities that can be observed from the behavior displayed. Behaviors routinely shown to other 50 people can be approaches, activities, efforts, roles articulated or actualized by research subjects. Then the researchers gave a qualitative and in-depth explanation (verstehen) about the role of school committees in improving the quality of education management.

\section{RESULTS AND DISCUSSION}

The Decree of the Minister of National Education expressly states that the school committee is an independent business entity that accommodates the community's participation to improve the quality, 
equity, and efficiency of education management in the education unit. Furthermore, the decree of the minister of national education number 044/U/2002 confirmed that the board of education is domiciled in the district or city. Simultaneously, the school committee is located in education, school education, and madrasah and nonformal education. The school committee also carries out four roles, as follows:

1. Advisory agency in determining and implementing education policy in the education unit;

2. Supporting agency in the form of financial, thought, and energy in the implementation of education in the education unit;

3. Controlling agency in the framework of transparency and accountability of the education unit's implementation and output;

4. As a mediator between the government (executive) and the school community.

In order for the school committee to play a good role in the formation of management must also be able to meet several principles/rules and mechanisms that are correct and can be managed by the public at large, starting from the stage of forming committee members are carried out accountable that committee members are responsible for their performance. As stated by the Principal of SD N 18 Muara Telang, he stated that:

"The mechanism of establishing the school committee of SD N 18 Muara Telang was first with a principal, teachers, and school staff meeting. Followed up with the next meeting invited several people, including local community leaders, parents of students who were considered potential, after those invited came, then we held deliberations and then conducted elections but in the management of this committee, none of the teachers involved in the management of the committee SD N 18 Muara Telang."

The same thing revealed by Panji Saputra as Chairman of SD N 18 Muara Telang Committee said:

"The selection of committee members and committee members was conducted in deliberation at SD N 18 Muara Telang. The school invited the parents to select committee members, and the management of this committee transparent. Besides, the teacher did not participate in this school committee's management, all submitted to the parents."

Formally, almost all schools already have school committee devices as community representatives in assisting education programs in schools. The school committee's presence has shown its stake as a school partner, especially for principals and teachers, to design and implement educational programs, both physical and non-physical development programs, following its role in improving education quality.

\section{a. As an Advisory Agency}

As the school board, the school committee has the meaning that the school committee is seen as a principal partner who can be invited to discuss its future. Through the school committee, parents and the community can participate, formulating the vision, mission, goals, and objectives that will be achieved by the school, to determine the ways or strategies that will be taken to achieve it in the form of policy formulations, programs, and school activities.

So far, the existence of school committees means a lot to every education unit. Because the school committee is the main helper of the unit in prospering educational institutions other than the school's internal community, all kinds of programs implemented by the school should first be consulted with the school committee because all kinds of policies will be implemented or implemented inseparably from the community's participation internally and externally school.

This is as stated by Mrs. Sudarni, S.Pd. as the Principal of SD N 16 Muara Telang stated that:

"The school committee gave special consideration to improve the quality of education, such as the procurement of laboratory equipment, rehabilitation of classrooms, and classroom construction plans. Before the school made a decision, discussions were held between the principal and the school."

The same thing was expressed by Mrs. Margareth, S.Pd. as the Principal of SD N 2 Muara Telang, as follows:

"The school committee, as the principal's partner, can consider every plan and program drawn up by the school. For example, the school will apply for the rehabilitation of damaged infrastructure and buildings. The school will add three classrooms, a plan to build a language laboratory, etc. So the school first consulted the school committee to provide input by the community's aspirations represented by the school committee. Furthermore, on behalf of the communities it represents, the school committee may express agree or disagree with the school's planned educational program."

The school committee's position as a giver of consideration continues to provide input and consideration in terms of the draft budget of school revenue and expenditure (RAPBS), unit performance criteria, criteria for education personnel, and educational facilities criteria. Based on the research interview results with the head o the school committee of SD N 2 Muara, it was found that to improve the quality of education at SD N 2 Muara Telang, school committees' involvement is comprehensive. Start by ranging from providing input and consideration in establishing school budgets, considering the process of managing education in schools, and identifying existing educational resources in the community to be considered and assisted in schools.

As a board that provides consideration or advice, the school committee in education planning can identify 
existing educational resources in the school and provide input and consideration in establishing the School Budget Plan (RAPBS) included in the RAPBS meeting. In the management of educational resources, including human resources, facilities and infrastructure, and budget allocation, the school committee serves as an indentation of various community educational resources. This function will be useful in considering educational resources that can be considered and assisted in schools.

In the implementation of the program, which concerns the curriculum, syllabus, teaching and learning process, and the school committee's assessment as an advisory board plays a vital role in considering the implementation of managing education in schools, including learning-based on the statement that in improving the quality of education the school committee participated in its involvement to implement the budget in the management of human resources, infrastructure, and allocation of school budgets.

\section{b. As Supporting Agency}

The committee's role as a supporting board for implementing and improving education quality can be financial support, energy, and mental support. This support can be realized, among others, by solving the problem of teacher shortages, school fees for underprivileged children, and assistance to help repair damaged schools. The empowerment of necessary facilities and infrastructure in schools through existing resources in the community is done in coordination with the educators' board. The supporting role held by the school committee is not only to provide encouragement and motivation but more than that. By acting as a supporting agency, the school committee can encourage and encourage parents and the community to participate in education. It is because educational institutions (units) can not act like a civilized and knowledgeable generation-forming institution without getting great support from the community.

A good education requires adequate facilities and infrastructure, adequate classrooms, and many costs. However, so far, the budget in schools is minimal; therefore, the community is expected to be in charge and donors who provide funds for the smooth running of educational activities in schools. Interested and sympathetic communities can assist in various means, such as providing props, books, and providing costs to underprivileged students. Schools can be more advanced and able to compete with other schools.

\section{c. As the Controlling Agency}

The school committee's next role is to control the framework of transparency and accountability of the implementation and output of education in schools. Supervision conducted by the school committee includes control over decision making and education planning in schools and allocating funds and resources for program implementers. The school committee also performs its control function on education success in schools as seen from the quality of educational output. The results of the supervision of schools will be used as sufficient consideration for the implementation of education and improving the quality of education.

The existence of this school committee also has many benefits. With the school committee, the aspirations of students and parents can be conveyed and represented. Also, the school always gets support from the school committee to continue improving the quality of education. As a mediator between the government and the community, the school committee strives to provide a clear briefing and information on government policy in the world of education. This is aimed at providing public understanding that the government always improves the quality of public education. Based on the information above, it can be concluded that the role that has been done by the school committee in improving the quality of education in Cluster 01 of Muara Telang Sub-District of Banyuasin Regency is quite good. This is evidenced by school committees' concern, especially parents, to help, support, and participate in the sustainability and development of education.

\section{CONCLUSION}

The school committee is influential in improving Cluster 01 of Muara Telang Subdistrict's quality of education in Banyuasin Regency. This is because the school committee has several roles to play for the school. The school committee's many roles towards improving the quality of education in Cluster 01 Muara Telang District Banyuasin found in this research. First, Giving consideration (advisory agency) in planning programs prepared by the school, such as repair and procurement of infrastructures, such as classroom improvement, procurement of props, laboratory construction, and classroom development. Besides, the school committee also provides input and consideration in establishing the School Budget, giving consideration in the implementation of the school's education management process, and identifying the educational resources that exist in the community to be able to be assisted for school development. Second, supporting the implementation and improving the quality of education in Cluster 01 of Muara Telang District, Banyuasin Regency in financial support, energy, and mental support. Third, Controlling the agency for decision making and planning of education in schools and the allocation of funds and resources for the implementation of programs in school committees also performs its control function to the success of education in schools judging by the quality of education. Fourth, as a mediator or liaison between parents' aspirations to the school and participate in socializing school policy to the relevant parties and authorities at the regional level. 


\section{REFERENCES}

[1] Mulyasa, E. (2006). manajemen berbasis sekolah. Bandung: PT. Remaja Rosada Karya.

[2] Mulyasa, E. (2013). Manajemen dan kepemimpinan kepala sekolah. Jakarta: Bumi Aksara

[3] Hasan, H. (2014). Jurnal: Fungsi Komite Sekolah Dalam Perkembangan Dan Implementasi Program Sekolah Di Sd Negeri 19 Kota Banda Aceh. FKIP Unsiyah.

[4] Meleong, L. J. (2013). Metodologi Penelitian Kualitatif, Edisi Revisi (Bandung: Remaja Rosdakarya) hal. 4
[5] Sukmadinata. (2008). Pengendalian Mutu Pendidikan Sekolah Menengah (Konsep, Prinsip, dan Instrument), Bandung: PT Refika Aditama.

[6] Tilaar, H. A. R. (2009). Standarisasi Pendidikan Nasional. (Jakarta: Rineka Cipta) h. 109

[7] Undang-Undang Republik Indonesia No. 20 Tahun 2003 tentang Sistem Pendidikan Nasional (Sisdiknas) Bandung: Fokusmedia 